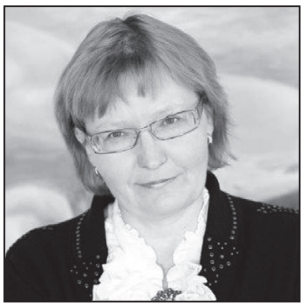

Kersti Kerstna-Vaks

Mag. iur.

Judge Tartu Circuit Court

\title{
Available Options for Funding the Insolvency Proceedings of Corporate Debtors
}

\section{Introduction}

As a general rule, insolvency proceedings ${ }^{*}{ }^{*}$ are funded from the insolvent debtor's assets. Yet there are many cases in which those assets are insufficient to cover even the cost of the proceedings. Different jurisdictions apply different principles when deciding whether the courts should declare bankrupt an insolvent debtor who has no assets and when allocating the burden of funding such proceedings.

In order for insolvency proceedings to be conducted efficiently, there must be legal clarity as to their funding at least as to the following issues: 1) May the court require the person who filed for bankruptcy to pay a deposit to the court to cover potential costs incurred in the course of the proceedings? 2) What are the requirements for funding after the declaration of bankruptcy? 3) Would it be possible to finance the work of the trustee in bankruptcy from public funds? Clarity on these issues lays the foundations for efficient and purposeful conduct of the proceedings. In the UK, the courts have found that neglecting to provide funding for insolvency proceedings is likely to further increase the number of directors who breach their obligations and to give such directors an incentive to clean out the debtor's assets. ${ }^{{ }_{2}}$ The existence of public interest in scrutinising the actions of insolvent companies whose assets are insufficient to cover the cost of the proceedings has been stressed also in UNCITRAL recommendations. ${ }^{*}$ For this reason, the author will focus in this article specifically on issues connected to funding the insolvency proceedings of corporate debtors.

Where the insolvent corporate entity has no assets, Estonian bankruptcy law allows the courts to terminate the bankruptcy proceedings on account of abatement. Abatement terminations have been severely criticised, yet no provision has so far been made to allow public funds to be used to pay the costs associated with the proceedings, and the creditors rarely exhibit anything beyond a feeble interest in providing supplementary financing. The same conclusion was reached in the pilot study of the efficiency of bankruptcy

1 The author employs the terms 'bankruptcy' and 'bankruptcy proceedings' in the meaning that they have in the Estonian Pankrotiseadus (Bankruptcy Act), publication reference in RT I 2003, 17, 95; publication reference of the last amendments 9.5.2014, 14. For the purposes of said act, the term denotes proceedings with a view to liquidation of the debtor, unless the creditors decide to reorganise the debtor's business. The terms 'insolvency' and 'insolvency proceedings' are used where the reference is broader or concerns specific jurisdictions that employ the terms.

2 Eastglen Ltd v. Grafton, 1996 2BCLC 279 at pp. 292-293, referred to in A. Keay, P. Walton. Insolvency Law: Corporate and Personal. Pearson-Longman 2003, p. 383.

3 UNCITRAL Legislative Guide on Insolvency Law 2005, p. 62. Accessible at the URL http://www.uncitral.org/pdf/english/ texts/insolven/o5-80722_Ebook.pdf (most recently accessed on 24.2.2015). 
proceedings that was commissioned by the Estonian Government Office in $2013^{*} 4$, which also produced policy recommendations dealing with the funding of corporate bankruptcy proceedings.

The aim of this article is to analyse the options available for financing the insolvency proceedings of corporate debtors and to assess their impact on the funding of the costs of the proceedings and the efficiency of proceedings. An opportunity to combine different funding arrangements makes it possible to take into consideration different aims of insolvency proceedings and the debtor's obligation to file a bankruptcy petition before it is too late. In consideration of the length limitation that the article must respect, the author has excluded from analysis the specific issues related to the costs arising in connection with the actions filed by the bankruptcy trustee.

\section{The options for funding insolvency proceedings}

The funding of bankruptcy proceedings means making available the funds required for paying the costs of the proceedings, including the fee of the interim trustee and of the trustee in bankruptcy, along with the reimbursement of the necessary expenses incurred by them in connection with the performance of their duties (see §150 (1) of the Bankruptcy Act, hereinafter 'BA'). In a more general sense, the consolidated obligations (set forth in $\S 148$ of the BA) arising in the course of the proceedings can also be regarded as falling in the category of costs, because they have been incurred after the declaration of bankruptcy and have priority over the claims of bankruptcy creditors.

Under $\$ 150$ (2) of the BA, the proceedings that follow the declaration of bankruptcy are to be funded out of the debtor's estate. This represents the regular funding arrangement. Other, extraordinary arrangements, extending beyond this, must be found when the estate is insufficient to cover the cost of the proceedings. Said extraordinary arrangements are primarily deposits by creditors, assistance from public funds, or post-commencement financing, all of these aimed at financing the trustee's activities in creating new assets and/or expanding the debtor's estate. Also, public funding may be granted for ascertaining the reasons for the bankruptcy or to protect other public interests. It is the author's view that the courts must, when declaring a bankruptcy, know where the money to fund the ensuing proceedings is to come from.

In Estonia, the rules that govern extraordinary funding arrangements make a distinction between creditor- and debtor-petitioned bankruptcies. If the petition is brought by a creditor, the court has the power to order the creditor to pay a deposit to cover the cost of the proceedings when it has reason to believe the debtor's estate inadequate for the task (see $\S 11$ of the BA). Under $\S 30$ of the BA, creditors are entitled but not obliged to pay the deposit required for avoiding the termination of proceedings on account of abatement. Failure by the creditors to pay the deposit releases the court from the obligation to declare the bankruptcy, and proceedings then are terminated on account of abatement (under §§ 29 (1) and 29 (2) of the BA). If the court, however, declares the bankruptcy and the trustee has consented to be appointed, the court is no longer responsible for the absence of assets to cover the cost of the proceedings, and the trustee must perform his duties until the proceedings are closed, whether he is paid or not. ${ }^{{ }^{5}}$

The trustee is authorised, subject to approval by the creditors' committee, to borrow funds in order to conduct the proceedings ( $\$ 125(4), \mathrm{BA})$. Public funds are available only to pay the fee and expenses of the interim trustee, provided that the corporate debtor itself filed for bankruptcy and its assets are not sufficient to cover the cost of the proceedings ( $\$ 23(4), \mathrm{BA})$. A creditor who has brought a bankruptcy petition must bear the costs of the proceedings if the court refuses to declare the bankruptcy ( $\$ 150$ (3), BA).

The following sections look at the various funding options in more detail.

4 Maksejõuetuse menetlemise tõhususe uuring 2013 (A study of the effectiveness of insolvency proceedings), commissioned by the Estonian Government Office, carried out by AS PricewaterhouseCoopers Advisors (in Estonian). Available at http:// valitsus.ee/UserFiles/valitsus/et/riigikantselei/strateegia/poliitika-analuusid-ja-uuringud/tarkade-otsuste-fondi-uuringute-kokkuvotted/Maksej\%C3\%B5uetuse_menetlemise_t\%C3\%B5hususe_uuring.pdf(most recently accessed on 10.5.2013). The data used in the study include approximately 3,500 cases in Estonia from the period 2004-2012.

5 For instance, in the Netherlands, the courts give no regard to the presence or value of assets that are part of the debtor's estate when declaring the bankruptcy. Under certain circumstances, the insolvency representative will be entitled to apply for public assistance to pay his preliminary fee. See H. Vallender (ed.). The Role of the Judge in Nomination, Supervision and Removal of the Insolvency Representative. Nottingham; Paris: INSOL Europe 2014, p. 103. 


\section{Payment of the costs from the debtor's estate}

In Estonia, members of corporate management boards have a statutory duty to file for bankruptcy without delay when the corporate body has become permanently insolvent. ${ }^{* 6}$ The timely filing duty is intended, amongst other things, to provide for the presence of resources for the financing of bankruptcy proceedings, including the payment of their costs. In practice, however, this mechanism does not function as intended.

According to the study commissioned by the Estonian Government Office, during their last year of operation, $50 \%$ of the corporate bodies whom the courts found to be permanently insolvent held assets worth less than 1,000 euros. In 2004-2012, 58\% of corporate bankruptcy proceedings were terminated on account of abatement without a declaration of bankruptcy. ${ }^{*} 7$ Thus, in these cases, there were no assets from which to cover the cost of the proceedings, nor was there any interest on the part of the creditors in financing them. It should be taken into account that, even where it is possible to expand the bankruptcy estate (by recovering or reclaiming property), this presumes expenditure for the drawing up of actions and the payment of court fees and security deposits. Where the debtor's assets prove insufficient to cover the cost of bankruptcy proceedings, it is possible to close the case on grounds of abatement also after the declaration of bankruptcy ( $\$ 158(1), \mathrm{BA})$, and the trustee is required to notify the court of such situations without delay.

The debtor's assets may prove insufficient to cover the cost of the proceedings also in cases wherein they have been encumbered with a security interest. Only a portion of the proceeds from the sale of the property subject to the security interest may be used to pay the expenses incurred by the trustee. Under $\$ 153$ (2) of the BA, secured creditors may only be required to contribute toward the cost of the proceedings $15 \%$ (excluding VAT) of the proceeds from the sale of the property in which they hold the security interest. ${ }^{* 8}$ The limitation has been enacted for the protection of the interests of security holders in order to guarantee the satisfaction of the lion's share of the secured creditor's claim also in bankruptcy proceedings. Yet such a limitation may pose problems with respect to covering the actual and necessary costs of bankruptcy proceedings, including payment of the trustee's fee. This conflict has resulted in a number of legal disputes between bankruptcy trustees and secured creditors. The trustees have argued that the relevant provisions may not be interpreted so as to result in a situation in which the trustee has performed his duties in the bankruptcy proceedings yet cannot even be paid the statutory minimum fee because of the restriction laid down in the BA's $\S 153$ (2). ${ }^{*}$

The Supreme Court has on numerous occasions scrutinised the extent of the duty of secured creditors to contribute to financing the proceedings and has found that the ceiling provided in $\$ 153$ (2) of the BA must be regarded as an absolute value that applies to all types of payment mentioned in $\$ 146$ (1), including the trustee's fee. ${ }^{* 10}$ Should the trustee succeed in selling secured property for a sum that exceeds the relevant creditors' secured claims, those claims would be satisfied in full and the creditors would not have to pay any costs at all. In such a case, the difference between the proceeds from the sale and the payment made to the secured creditors may be used to make the payments listed in $\$ 146$ (1) of the BA. ${ }^{* 11}$ This means that in Estonia secured creditors' rights have priority over payment of the cost of the proceedings. The author finds nevertheless that, where the secured creditor agrees, the trustee is allowed to use a greater proportion than $15 \%$ of the proceeds for payments under $\$ 146$ (1) of the BA.

It is important to note that this is liable to place control over the conduct and fulfilment of the aims of the proceedings in the hands of the dominant secured creditor. In consequence, the interests of creditors who do not hold privileged claims may be affected, as may ascertainment of the reasons for the debtor's

6 This obligation arises from sections 36 and 44 of the General Part of the Civil Code Act, as well as from the specific rules (§§ $306(1)$ and $180\left(5^{1}\right)$ of the Commercial Code).

7 See Note 4 for the reference. The high number of abatement terminations suggests the absence of a bankruptcy culture. See A. Jäger. Pankrotikultuuri parandamisele peaksid tõuke andma ettevõtjad (Improvement of the Bankruptcy Culture Should Be Led by Entrepreneurs) (in Estonian). Available at http://blog.krediidiinfo.ee/2013/o3/pankrotikultuuriparandamisele-peaksid-touke-andma-ettevotjad/ (most recently accessed on 10.5.2013).

8 This limitation applies as of 1 January 2004. Before that, there were no restrictions as to the sums from the proceeds of the sale of secured properties that the trustee was allowed to spend on covering the expenses or consolidated obligations, provided that the court approved the payments. See also CCSCd 3-2-1-92-10.

9 CCSCd 3-2-1-167-11.

10 $\quad \operatorname{CCSCd} 3-2-1-44-05 ; 3-2-1-126-06 ; 3-2-1-167-11$.

1 CCSCd 3-2-1-167-1. 
insolvency (one of the aims of the proceedings) and the independence of the trustee. ${ }^{* 12}$ Insolvency proceedings are proceedings of a collective nature and are therefore intended to fulfil several aims. Their main aim, as scholars universally agree, lies in providing the best possible satisfaction of the creditors' claims (§2 BA). Satisfying only the claim of the privileged creditor does not actually attain the main aim of the proceedings, especially in a situation wherein satisfaction of the claims held by the rest of the creditors would be subject to the existence of assets to cover the cost of the proceedings. The relevant statutory rules indicate that the Estonian legislature intended to protect the rights of privileged creditors, hoping that $15 \%$ of the proceeds from the sale of secured property is sufficient to cover the cost of the proceedings also in cases in which the debtor holds no other assets. ${ }^{* 13}$

Hence, even where the debtor is not assetless, its assets, if subject to security interests, may not be enough to pay all costs that are required to complete the proceedings in the case. The author finds that policymakers ought to consider differentiating the proportion of the proceeds from the sale of secured property that may be used to cover the cost of the proceedings and vesting the courts with the authority to determine the specific proportion. Such a solution would correspond better to the collective nature of insolvency proceedings. The expenses related to preserving and realising a property subject to security interests should be borne exclusively from the proceeds of sale of that property.

There are no other statutory restrictions on the cost of the proceedings in Estonian bankruptcy law (except for the trustee's fee).

In conclusion, it should be pointed out that when making expenditures from the debtor's estate, trustees should always be mindful of the fact that they operate in the aftermath of business failure and that any expenses incurred must be strictly necessary for the fulfilment of the aims of the proceedings. Already at the start of the case, the trustee should be able to estimate the extent of required expenditure and provide the court with the corresponding information in his report on the debtor's estate ( $\$ 132 \mathrm{BA}$ ). Where most of the estate is subject to security interests, the trustee may expect only the statutory minimum funding to be available to pay the costs - unless he obtains the consent of secured creditors to contribute a larger proportion of the sum to which they are legally entitled.

\section{Funding of the proceedings via contributions from the creditors}

The prevailing opinion in Estonia is that in cases wherein the assets of a corporate debtor's estate are insufficient, the insolvency proceedings of the debtor must be paid for by the parties presumed to benefit from them: the creditors. This view has received considerable indirect support in the case law of the Supreme Court pertaining to trustees' applications for exemption from the payment of court fees. ${ }^{*}{ }^{14}$

Already the creditor's right to bring a bankruptcy petition against the debtor is subject to the duty to guarantee the presence of funds to cover the expenses of the interim trustee where this appears necessary $(\S 11, \mathrm{BA})$. In the case law on the subject, disputes have arisen as to the amounts that the courts have set as the deposit. The setting of the amount is fully within the discretionary power of the court, and the resulting orders may be set aside by the higher courts only where the lower court has clearly overstepped the bounds of its discretion. ${ }^{*} 15$

Requiring the creditor who brings a bankruptcy petition against its debtor to make a security deposit is a practice that is known also in other jurisdictions. In Poland, the courts are authorised to require the petitioning creditor to make a deposit payment in order to ascertain whether or not there are valid reasons for declaring the bankruptcy. When a declaration of bankruptcy has been entered, the overseeing judge

12 R. Goode. Principles of Corporate Insolvency Law, 4th edition. Sweet and Maxwell, 2011, p. 79.

13 See also J. Westbrook. The control of wealth in bankruptcy, 82 Texas L. Rev 795 (2004). The article analyses the interplay of secured creditor rights and bankruptcy proceedings and stresses the importance of centralised control over the bankruptcy estate in the course of the proceedings.

14 The Supreme Court has stated in several decisions (on cases 3-2-1-19-12, 3-2-1-13-09, and 3-2-1-18-08) that there is a presumption under which a party who holds a financial interest can bear the costs of the proceedings required to enforce it. In the case of actions brought by the trustee in bankruptcy, the parties who hold the corresponding financial interest will be the creditors.

15 CCSCd 3-2-1-171-12; 3-2-1-13-13. 
will decide whether to require the creditor that holds the largest claim (the claim must exceed $30 \%$ of the total sum of all claims against the estate) to provide a deposit or to convene a general meeting of the creditors to settle the matter of costs. Should the creditors fail to pay the cost of the proceedings, the case will be closed. ${ }^{*}{ }^{*}$ In the Czech Republic, the courts may require the party who files the bankruptcy petition (i.e., also the debtor) to make a deposit of up to 2,000 euros toward the costs. ${ }^{*}{ }^{* 17}$ In Germany, creditors are entitled to make deposits to guarantee the conduct of the proceedings. ${ }^{*}{ }^{* 18}$ Prior to declaring the bankruptcy, the court must make sure that there are sufficient funds to cover the cost of the proceedings, for bankruptcy proceedings are opened in the interests of the creditors and not of the public. ${ }^{* 19}$ If the funds are insufficient to cover the costs, the case will be closed ( $\$ 207$ of the Insolvenzordnung, or InsO). The provision reflects the decision of the German legislature to terminate proceedings that are unable to raise the funds to cover their costs, let alone satisfy the creditors' claims. ${ }^{*} 20$

The author holds the view that the requirement that a creditor pay a deposit to cover the cost of the proceedings must not amount to an unreasonable limitation of the creditor's right to file a bankruptcy petition against the debtor and that the creditor should be entitled to request assistance from public funds in line with standard procedure for such assistance. The case law on the subject reflects the view that the expenses incurred by the interim trustee must be considered on the same footing as those of expert witnesses and, accordingly, represent a cost of the proceedings toward which a natural-person creditor is entitled to request public assistance. ${ }^{* 1}$ The deposit required for the bankruptcy to be declared does not, as a rule, have to be sufficient to cover all possible expenses of the trustee. It is for oversight by the court and by the creditors to ensure that the amount of the deposit is commensurate to the needs of the case and that the trustee uses the money prudently.

V. Finch has expressed the view that the creditors' potential inclination to finance insolvency proceedings is frustrated by their length and by fear that the trustee may not use the money collected from the creditors in their best interests. Moreover, it is not possible to offer those creditors who choose to finance the proceedings a larger proportion of the proceeds than those creditors are entitled to under the pari passu principle. ${ }^{* 22}$

Currently, the only guarantee for the creditors who finance the proceedings is that the sums they pay as a deposit will also be classified as a cost of the proceedings and consequently are to be repaid with priority over disbursements to ordinary creditors ( $\$ 150(6), \mathrm{BA})$. The author finds that in, order to increase the creditors' interest in financing insolvency proceedings, Estonian legislators should consider granting additional rights to the financing creditors with respect to the distribution of the debtor's estate. For instance, the claims held by ordinary creditors who agree to finance the proceedings might be recognised to a certain extent as privileged claims. This derogation from the principle of equal treatment of the creditors would be justified by the consideration that in the absence of funds to cover the cost of the proceedings, the case would abate and the creditors would not receive any satisfaction at all.

\section{Post-commencement financing}

Post-commencement financing may be provided, amongst others, by an ordinary creditor who already holds claims against the debtor and who is interested in committing additional funds to the case in order to secure the existing claim and to earn interest at a higher rate. Under UNCITRAL recommendations, postcommencement financing should be regarded as part of the cost of the proceedings. The resulting claim would not have priority over secured claims yet would come before claims of unsecured creditors or receive priority in situations wherein public claims would otherwise have priority. There are jurisdictions where

16 D. Faber et al. (eds). Commencement of Insolvency Proceedings. Oxford University Press, 2012, pp. 493-494.

17 Ibid., p. 255

18 Ibid., pp. 329-330.

19 E. Braun (ed.). Commentary on the German Insolvency Code. Düsseldorf, Germany: IDW-Verlag GmbH 2006, p. 111.

20 H. Vallender (ed.). The Remuneration of the Insolvency Representative in Europe. Nottingham; Paris: INSOL Europe, 2012, p. 42.

21 Tartu Court of Appeal, order in civil case 2-13-3634.

22 V. Finch. Corporate Insolvency Law: Perspectives and Principles. Cambridge University Press, 2002, p. 386 DOI: http:// dx.doi.org/10.1017/CBO9781139164283 . 
post-commencement financing is treated as having 'super-priority'; i.e., the post-commencement creditor is prioritised over other persons to whom the debtor owes consolidated obligations. The author considers such treatment well founded because it appears the most suitable as a guarantee for the claims held by postcommencement creditors.

Post-commencement borrowing requires the corresponding decisions by the trustee and the creditors participating in the proceedings, along with their general preparedness to underwrite new risk with a view to improving the outcome of the proceedings. Under the UNCITRAL recommendations, jurisdictions should establish rules to govern the conditions of post-commencement financing and provide protection to post-commencement creditors, as well as to the parties whose interests may be jeopardised by the provisions for such funding. ${ }^{*} 23$

An important question arises in connection with the allocation of authority to decide on post-commencement borrowing. The need for supplementary financing may necessitate speedy decisions, which suggests that the number of approvals required should be reduced to a minimum. Although involving the courts tends to result in more transparency and provide additional security to the creditor, it will still often be the trustee who holds the information requisite for evaluating the need for borrowing. If the law grants priority for post-commencement creditors over ordinary creditors, court authorisation for the borrowing will not be necessary. Under UNCITRAL recommendations, authorisation by the court should be required when the priority of post-commencement financing or the guarantees connected to it affect the interests of secured creditors. Post-commencement borrowing should be subject to the principle that the economic value of secured creditors' claims must be guaranteed also when the decision to borrow is made. ${ }^{*} 4$

In the US, the provision of post-commencement financing to insolvent companies has turned into an industry in its own right. Such financing represents high-risk loans provided at high interest rates. The loans must be authorised by the court. Post-commencement creditors are granted priority over all other creditors except secured creditors. Where the debtor possesses yet unencumbered assets, the court may authorise the granting of a security interest to the post-commencement creditor. ${ }^{*} 25$ In the Netherlands, post-commencement creditors are not granted priority over secured creditors, and the trustee does not require court authorisation to effect the borrowing. ${ }^{* 6}$ In Australia, the trustee is not required to obtain the approval of the court or the creditors for his decision to borrow. Post-commencement borrowing is regarded as a transaction executed by the trustee and, as such, commands priority of repayment over the claims of ordinary creditors. ${ }^{*} 7$

In Estonia, trustees rarely resort to borrowing to finance the proceedings. Borrowing would presume the approval of the creditors' committee - which is perfectly understandable, given that it is the creditors (through the creditors' committee) who exercise oversight of the expediency of the trustee's actions. In this connection, the Supreme Court has ruled that a loan agreement entered into by the trustee is not rendered null and void by mere absence of the approval of the creditors' committee. Where the funds borrowed are used in a manner that is incompatible with the purpose of the proceedings, the trustee will be liable for repayment of the loan. ${ }^{*} 28$

In this author's view, the rights of post-commencement creditors are well protected under Estonian bankruptcy law, because post-commencement borrowing is regarded as a transaction of the trustee and qualified as a consolidated obligation, which means that it holds priority of repayment over debts to ordinary creditors ( $\$ 146$ (1) 3), BA). There is no requirement to obtain the court's authorisation for the borrowing, because it does not affect the rights of secured creditors and because in Estonia the courts are charged only with overseeing the lawfulness of the proceedings.

Although the UNCITRAL recommendations include the provision of a security interest to post-commencement creditors, this appears problematic in the Estonian setting in that debtors' estates rarely include assets that have not been pledged 'to the hilt'. The only unburdened assets of the estate are likely to be those that the trustee succeeds in recovering. The question then would be whether or not to allow recovered assets

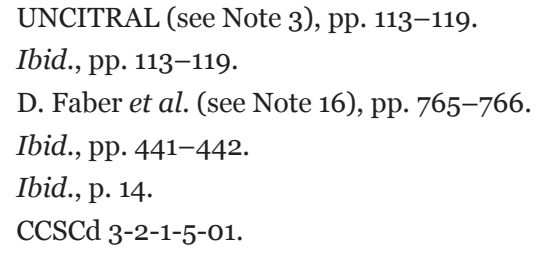


to be encumbered with security interests. ${ }^{* 29}$ The author represents those holding the view that this should be allowed because there appears to be no valid reason for providing an exception to the regime of security interests on the grounds that a property entered the debtor's estate in a specific manner.

All in all, it appears that trustees should consider borrowing primarily in cases wherein the creditors decide to reorganise the debtor's business. In such cases, the trustee can include the need for post-commencement borrowing in the reorganisation plan. The Supreme Court has ruled that borrowing may be necessary for the administration of the debtor's estate (an economic activity) just as much as for the inventorying and sale of the assets in order to achieve satisfaction of the claims of the creditors - the aim of the proceedings - as provided for by law. ${ }^{*} 30$ The risk of default is reduced via the competence of the trustee and by oversight on the part of the court and the creditors. It would also be possible to create a security interest in respect of the post-commencement borrowing.

\section{Public assistance for paying the cost of the proceedings}

Views on the need for public assistance in funding of insolvency proceedings vary widely from one jurisdiction to the next. The dominant view in the UK is that no insolvency case should be left unscrutinised for lack of the requisite funds. The insolvency practitioners will accept a case if they are certain that their expenses will be covered from the debtor's estate; in other cases, the courts will appoint an official receiver. ${ }^{*}{ }^{11}$ Unlike under the regimes of other jurisdictions, official receivers in the UK are held to exercise public authority. ${ }^{*} 2$ In Germany, on the other hand, the courts will not declare a debtor bankrupt unless there are funds to cover the cost of proceedings ( $\$ 26$ (1) InsO). There are no public funds available for corporate insolvency proceedings, save for the fees of the experts required to ascertain whether the debtor's assets are sufficient to cover the costs. ${ }^{*} 3$ According to the information presented in Commencement of Insolvency Proceedings (2012), also among the countries that provide no public assistance to fund insolvency proceedings are Poland, Spain, China, Belgium, and Brazil. ${ }^{*} 4$

In addition to distributing the insolvent debtor's assets among its creditors, in contemporary society the bankruptcy trustee fulfils a number of other public tasks (preserving jobs and protecting the environment, fighting against tax fraud and other crime, etc.), which might lead various legislatures to consider paying (some of) the trustee's expenses. In the Netherlands, the national tax office compensates the trustee for expenses that are directly related to establishing the commission of bankruptcy fraud. There is also a fund administrated by the Ministry of Justice that provides guarantees to the trustees with respect to the obligations they may incur by virtue of the actions they initiate before the courts, including payment of the costs of the adverse party in cases in which judgement is delivered against the trustee. Trustees may only apply to the guarantee fund if the debtor has no assets. There is currently discussion as to whether public funding should be made available also to cover the expenses of the investigation that the trustee might undertake to examine possible insolvency fraud. ${ }^{*} 35$ In Sweden too, the government will (with certain exceptions) provide public funding for proceedings in cases in which the debtor's assets are insufficient. ${ }^{*}{ }^{6}$ In the Czech Republic, the tasks of the trustee may be performed by an official receiver. ${ }^{*} 37$ The Australian government has created the Assetless Administration Fund to finance proceedings in respect of insolvent debtors with no assets. ${ }^{*} 8$

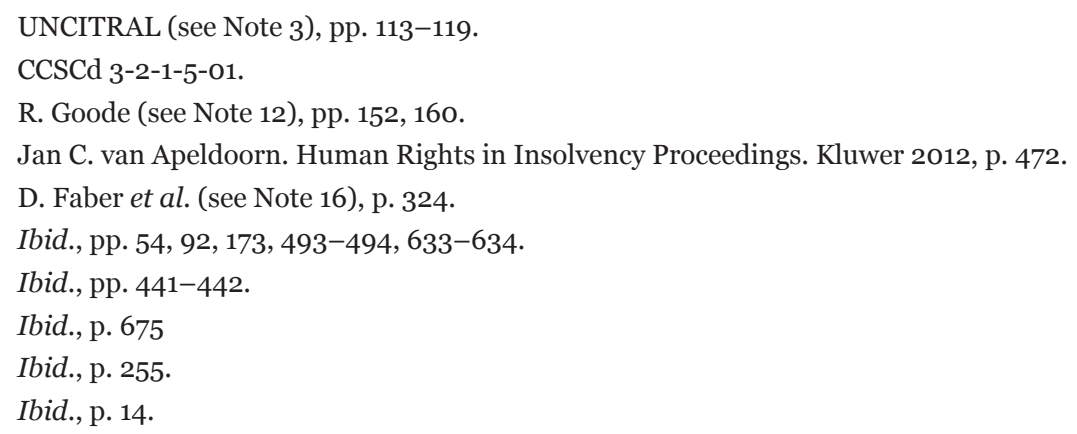


In Estonia, the need to provide public funding for insolvency proceedings in certain cases has been grasped only in the last decade. The possibility of financing the work of the interim trustee in assetless insolvencies by up to 397 euros per case from public funds allows the trustee to ascertain, amongst other things, whether the assets are sufficient for bankruptcy proceedings to be conducted. There is no official receivership in Estonian bankruptcy law.

The author supports the appointment of an official receiver as an alternative to the abatement of proceedings in insolvency cases in which the debtor lacks the assets to pay the costs and that the creditors are not interested in financing yet in which there are grounds to believe that the insolvency was caused by acts of a criminal nature or grave errors in management. The exemplar in this respect is Finland, which has made provision for the bankruptcy ombudsman to order special scrutiny funded by public monies to ascertain the facts of the case in assetless insolvencies. Where this is requested by the ombudsman, the court may declare the assetless debtor bankrupt and nominate an official receiver, who is then appointed by the ombudsman. The official receiver has the same duties as the bankruptcy trustee and must possess the same qualifications (as a rule, the trustee appointed in the case stays on as the official receiver). ${ }^{*} 39$

The primary purpose of insolvency proceedings is to provide the best possible satisfaction of the creditors' claims. Hence, in jurisdictions wherein the proceedings are focused exclusively on the interests of the creditors, policymakers have not deemed it necessary to allocate public money to pay for their costs. The author finds that in jurisdictions that link insolvency proceedings to a broader range of aims (including ascertaining the causes of the insolvency) and that recognise those aims as having a public interest component, public funding for conducting the proceedings should be available to a greater extent than the minimum costs of the interim trustee. Otherwise, achievement of the aims of the proceedings would be jeopardised. The provision of public funding (including appointment of an official receiver) would make it possible for the trustee to expand the asset pool of the debtor's estate for all creditors and include in that pool claims against the individuals who are responsible for the insolvency and/or who unduly delayed the filing of the bankruptcy petition. The decision to authorise public funding should be taken on the merits of each case and be based on the importance of the public interest at stake. The need to combine different sources of funding in such cases is also stressed in the UNCITRAL recommendations. ${ }^{*} 40$

\section{Payment of the cost of proceedings by the corporate debtor's directors}

P. Manavald has expressed the view that in a situation wherein the predominant form of insolvency proceedings is liquidation proceedings, the debtor has no incentive to request the opening of proceedings at an early stage, because it cannot participate in the resulting redistribution of resources. ${ }^{*}{ }^{1}$ For this reason, bankruptcy filings by debtors tend to be late.

It has also been suggested in Estonia that in the cases of debtors whose assets are insufficient to cover the costs of the proceedings, those costs should be borne by the individual who delayed the filing of the petition. The Supreme Court has stated that under Section 146 (1) 2) of the Code of Civil Procedure a director may be ordered to pay the expenses of the interim trustee under the head of costs if that director has agreed to pay those costs in a declaration made or agreement submitted to the court. ${ }^{*}{ }^{2}$ In practice, individuals related to the debtor often concede being late in filing for bankruptcy and agree to pay the costs of the interim trustee but refuse to finance the proceedings that follow the declaration of bankruptcy, hoping for their abatement.

\footnotetext{
39 The 2015 INSOL Comprehensive Directory of Restructuring, Insolvency and Bankruptcy Professionals throughout the World. GTI Media 2015, p. 43; The Office of Bankruptcy Ombudsman. The responsibilities, the object of supervision and the field of action. Available at http://www.konkurssiasiamies.fi/en/index/responsibilities.html (most recently accessed on 24.2.2015).

40 UNCITRAL (see Note 3), p. 67.

41 P. Manavald. Maksejõuetusõigusliku regulatsiooni valikuvõimaluste majanduslik põhjendamine (Economic Effectiveness of the Regulatory Options for Insolvency Rules), $\mathrm{PhD}$ thesis for the University of Tartu Faculty of Law. University of Tartu Press 2009, pp. 153, 158 (in Estonian).

42 CCSCd 3-2-1-112-08.
} 
A creditor who has paid the deposit set by the court in the case of an assetless corporate debtor is entitled to claim the sum deposited from the individual who, in breach of the relevant duty, failed to file for bankruptcy in a timely manner ( $\$ 30$ (3), BA). The same rule is applied in German bankruptcy law (§26 (3) ,InsO), which additionally allows ordering the individuals who breached the duty to file for bankruptcy to make advance payments toward the cost of the proceedings (§26 (4), InsO).

The author does not believe that the financing of insolvency proceedings could be improved and the number of abatement terminations reduced by the passing of rules that make conducting the proceedings contingent on the payment of the costs by individuals connected to the debtor. Were (even if only in certain situations) such a financing arrangement to be imposed on directors, it could even entail additional delays in complying with the duty to file for bankruptcy. On the other hand, the court should have the power to order an individual who fails to file for bankruptcy in a timely manner to pay the sums deposited by a creditors or contributed from public funds in the ensuing proceedings.

\section{Conclusions}

As a rule, corporate insolvency proceedings are financed from the debtor's estate. If the debtor has no assets at the time it is declared bankrupt, the court should determine the sources from which the proceedings are to be funded or terminate them on account of abatement.

The author takes the view that, in resorting to extraordinary arrangements for financing the proceedings, the interests to be protected by the proceedings must be observed. The primary purpose of insolvency proceedings is providing the best possible satisfaction of the creditors' claims, this being the reason it is possible to allow the proceedings to be financed by the parties that stand to benefit from them - i.e., the creditors. The rights of creditors who finance the proceedings and those of post-commencement creditors must be protected by law.

With respect to financing of the proceedings, problems arise in cases wherein most of the assets of the estate are encumbered by security interests: the rights of the holders of such interests may readily clash with the rights of other creditors. It is important to avoid situations in which actual control over the conduct of insolvency proceedings shifts from the trustee to the security interest holder. The author's recommendation to Estonian policymakers in this regard would be to abolish the fixed proportion of the proceeds from sale of secured property that limits the extent to which those proceeds may be used to cover the cost of the proceedings and to vest the authority to determine the proportion in the court dealing with the case.

Since the aims of insolvency proceedings are connected to a variety of interests, including public ones, it should be possible to avoid abatement terminations in assetless-debtor cases by recourse to the scheme for assistance with court costs or by appointing an official receiver. It will more often than not be impossible to ensure that insolvency proceedings are at the same time efficiently supervised by the court, paid for by the creditors, and in service of the public interest.

Although it is necessary to have rules regulating the duties of the individuals responsible for the timely filing of corporate bankruptcy petitions in payment of the costs of the corresponding insolvency proceedings, this cannot resolve all of the problems encountered in the financing of such proceedings. Should the individual whom the court has ordered to make certain payments within a certain time (prior to the declaration of bankruptcy) fail to comply with the order, the funds for those proceedings will still be missing. However, such a regime would be consonant with the duty of the directors to submit the bankruptcy petition in good time. 